\title{
Strategies on Conservation, Improvement and Utilization of Underutilized Fruit Crops
}

\author{
Simrandeep Kour*, Parshant Bakshi, Arti Sharma, V.K. Wali, \\ Amit Jasrotia and Shilpy Kumari
}

\author{
Division of Fruit Science, Faculty of Agriculture, Sher-e-Kashmir University of Agricultural \\ Sciences \& Technology of Jammu, Chatha, Jammu- 180009, India
}

*Corresponding author

\begin{tabular}{|l|}
\hline Ke y w o r d s \\
$\begin{array}{l}\text { Conservation, } \\
\text { Utilization, Fruit } \\
\text { crops }\end{array}$ \\
\hline Article Info \\
\hline $\begin{array}{l}\text { Accepted: } \\
\text { 07 February } 2018 \\
\text { Available Online: } \\
\text { 10 March } 2018\end{array}$ \\
\hline
\end{tabular}

\section{A B S T R A C T}

The crops, which are neither grown commercially on large scale nor traded widely, may be termed as underutilized crops. Underutilized crops are lesser-known plant species in terms of marketing and research, but well adapted to marginal and stress conditions. The popularity of these horticultural crops varies from crop to crop and locality to locality, which however, can be enhanced to a greater extent through publicity. Since, the underutilized horticultural crops have a long history of consumption, the local people are aware about their nutritional and medicinal properties. From the ongoing research worldwide, it is evident that underutilized wild edible plants possess high nutritional value. These plant species were good source of vitamins and minerals, but have now become less important. There is need to compile and disseminate that knowledge in order to help maintain cultural traditions and facilitate research into food history and new food sources. Due to unsustainable market pressures and rapid urbanization, majority of these species have come to near extinction. A holistic approach is hence proposed which includes both in-situ and $e x$-situ conservation strategies, as well as re-governance of the market chain. Reinforcement of their domestication through standardization of cultivation practices, facilitation for supply of planting material and increasing the demands for the produce by exploring their uses, creation of awareness among consumers and establishing a good distribution network are also crucial for attaining sustainability.

\section{Introduction}

Global food security and economic growth now depends on a declining number of plant species. In human history, 40- 100,000 plant species have been regularly used for food, fibers, shelter, industrial, cultural and medicinal purposes (Magbagbeola et al., 2010). However, only a small number of plants are widely used. The remaining plant diversity is underutilized (Jaenicke et al., 2006). Agriculture in today's context is one of the most important sources of renewable wealth in the world. There are many plants species still lying unexplored and underexploited. Therefore, there has been focused attention by the researchers on exploiting alternative or underutilized plant species for multifarious use. Underutilized plants, in general, constitute those plant 
species that occur as life support species in extreme environmental conditions and threatened habitats, having genetic tolerance to survive under harsh conditions and possess qualities of nutritional and/or industrial importance for a variety of purposes. Kunkel (1984) discussed that once underutilized food crops are properly utilized, they may help to contribute in food security, nutrition, health, income generation and environmental services when properly utilized.

Underutilized fruit crops can be defined as fruit crops which are have value but not widely grown, rarely found in the market and not cultivated commercially (Agent, 1994). The underutilized foods can also be defined as "the foods which are less available, less utilized or rarely used or region specific" (William and Haq, 2002).

According to Dansi et al., (2012) many neglected and underutilized species are nutritionally rich and adapted to low input agriculture. The erosion of these species can have immediate consequences on the nutritional status and food security of the poor.

Their enhanced use can bring about better nutrition and fight hidden hunger. For example, many underutilized fruits and vegetables contain more vitamin $\mathrm{C}$ and provitamin A than widely available commercial species and varieties.

With the increasing population pressure, India is facing serious challenges of food security, unemployment and environment degradation. About 65 per cent of the Indian population is presently living in rural areas and 85per cent of these rural families are dependent on agrobased activities for their livelihood (Williams and Haq, 2002).

Hegde, (2002), suggested that staple crops face major challenges in the near future and a diversification away from over-dependency on staple crops will be important as part of the progress towards the goal of achieving security of food production. From past UUC's continue to play a persistent role in the subsistence and economy of poor people throughout the developing countries. Despite their potential for dietary diversification and the provision of micro-nutrients such as vitamins and minerals, they still continue to attract little research and development attention. Therefore, the developing countries like India are being encouraged to diversify their food exports by developing new resources. In India, there are large areas of marginal and wasteland, which are not suitable for cultivation of staple crops, either due to poor quality soil or lack of water resources. Most of UUC species are tolerant to harsh agro-climatic conditions; they have excellent potential for establishment on marginal and wasteland throughout the tropics.

According to Salvi, (2016) the use of plants has long been an intimate part of local cultures and traditions. Many neglected and underutilized species play a role in keeping alive cultural diversity associated with food habits, health practices, religious rituals and social exchanges.

Focusing attention on neglected and underutilized species is an effective way to help a diverse and healthy diet and to combat micronutrient and deficiencies, the so-called 'hidden hunger' and other dietary deficiency particularly among the rural poor and the more vulnerable social groups in developing countries. In reality, local communities have used these plant species for generations but the current loss of local knowledge means that their traditional uses are being forgotten. Many underutilized species can make an important contribution to a better diet for local communities. 
Major concerns which make a crop so called underutilized

Crop must have a scientific or ethnobotanical proof of food value.

Crop must have been cultivated, either in the past or only being cultivated in a specific geographical area,

It must be currently cultivated less than other conventional crops,

Crop must have weak or no formal seed supply system,

Crops are recognized to have indigenous uses in localized areas,

Received little attention from research, extension services, farmers, policy and decision makers and technology providers,

May be highly nutritious and/or have therapeutic medicinal or therapeutic properties or other multiple uses.

\section{Some underutilized crops of India}

There are many underutilized food crops in India and majority are not well known or well documented (Solomon, 1998). Singh et al., 2012 studied the diversity of underutilized vegetable crops species in North-East India. Bal (2003) studies the underutilized fruits for Punjab subtropics. The ethnobotanical data for all the underutilized species is still to be explored for such species. Some of the underutilized plant species are

\section{Underutilied Fruit}

\section{Aonla/Amalaki/Amla (Emblica officinalis)}

Aonla is a deciduous fruiting plant grown in many states of India. The tree is hardy, prolific bearer and a suitable choice for arid regions of the country (Mitra, (1999). Likewise, (Das, 2013) also reported on the presence and significance of this fruit in hilly regions of India. Amla is the most concentrated form of vitamin C (500-600 mg/100 g) found in the plant kingdom, and when the whole fruit is used rather than an active ingredient, the vitamin $\mathrm{C}$ is easily assimilated by the human body and has been found to have great antioxidant properties. It also contains proteins and minerals like calcium, phosphorus and iron. The high vitamin $\mathrm{C}$ content of fruit makes its wide use in Ayurvedic medicine. The tree has been regarded as sacred in India, worshipped as the Mother Earth and is believed to nurture humankind by its nourishing taste and also believed to stimulate purity.

\section{Medicinal significance}

The nutritional values of aonla are numerous and is recommended to be included as part of the daily diet. The fruit is the richest source of vitamin $\mathrm{C}$ and is a diuretic, aperient and laxative. It cures insomnia, scurvy, constipation, used as a cooling agent to reduce the effects of sun strokes. It is also useful for haemorrhage, leucorrhoea (Hasan, 2010). As an anti-oxidant, it prevents premature ageing. Aonla stimulate the isolated group of cells that secrete the hormone insulin. Thus it reduces blood sugar in diabetic patient (Iyer et al., 2009).

Aonla is also used in many hair tonics. It enriches the growth and hair pigmentation. It prevents premature graying and falling of hair. It strengthens roots of hair, maintains colour and luster. It is the main ingredient used in the shampoo and hair dye. Eating fresh fruit or applying its paste on hair roots improves hair growth and colour. Aonla powder and oil are traditionally used in Ayurvedic applications for the treatment of scalp and improves complexion, removes wrinkles and sun burns. 


\section{Ber/Indian Jujube (Zyziphus mauritiana)}

It belongs to the family Rhamnaceae. It is an ideal fruit tree for arid and semi-arid regions in tropical and subtropical climate where most of the fruit crops cannot be grown either due to lack of irrigation facilities or adverse climatic and soil conditions. Fruits are greenish yellow to reddish brown. It has a high amount of vitamin C (85-95 mg per 100 g). More vitamin $\mathrm{C}$ was found in the fruit flesh near the seed rather than near the skin of the fruit (Krivencov, 1970).

It is also a rich source of vitamin A and Bcomplex. The fruits can also be used for making several products like chutney, dried ber, murabba, jelly, etc. Wines can also be prepared from the fruits. The decoction from root and bark is good for dysentery and diarrhoea and leaf decoction is useful as gargle in sore throat and in bleeding gums. The seed kernels are aphrodisiac. The powder of ber roots has medicinal properties for curing ulcer, fever and wounds.

\section{Fig (Ficus carica)}

Fig was an important food crop in ancient civilization. It is a highly nutritious fruit consisting of $84 \%$ pulp and $16 \%$ skin. Besides, the fruit also contains protein, calcium, iron, vitamin $\mathrm{A}$ and thiamine at varying concentrations [19]. Figs are consumed as fresh or dried, preserved, candied or canned.

Fresh figs are nutritious and used as dessert or for making jam, jelly, pudding, cakes, etc. The fruit is valued for its laxative property. It is applied for boils and other skin infections (Polumin, 1965 and Font, 1973). The latex is used to coagulate milk (Morsli, 1985) and leaves are used medicinally as diuretic, demulcent, emollient and anthelmintic properties.

\section{Karonda (Carissa carandas)}

It is a hardy, evergreen, spiny and indigenous shrub which thrives well as rainfed crop. The fruit belongs to the family Apocynaceae. Fruits, sour and astringent in taste, are a very rich in iron contains a good amount of vitamin C. They also contains protein, carbohydrates, fat, fibre and calcium. The ripened fruits may be eaten as dessert or used for the preparation of jelly, sauce, carissa cream or jellied salad. Unripe fruits are used for making pickles, sauces and chutney. The dried fruits may act as a substitute for raisins Cheema (1971). The wine prepared from ripe fruits contains about 14.5 to $15 \%$ alcohol and is very much liked by wine fanciers Nalawadi (1975). Fruits can also be used in dyeing and tanning industries. Karonda fruit is considered to be antiscorbutic and is also very useful in curing anaemia, stomach ache and is anthelmintic. Root extracts are used in lumbago, chest complains and venereal diseases Achenbach, 1989.

\section{Tamarind (Tamarindus indica)}

It is native to Tropical Africa and belongs to the family Fabaceae. It is the 'Indian date' and is one of the most important fruits of India. In Tripura, it is locally called "tentul" (Das, 2013). It is a large sized, long-lived evergreen tall tree with a spreading crown. It is an excellent tree for social forestry and agro forestry. This crop is highly suitable for wastelands due to its multi ferrous uses and capacity to withstand adverse agro-climatic conditions. It also acts as a good wind break. Almost every part of the tree finds some uses but fruit is the most useful which contains the sweet acidic pulp. The pulp has low water content and high levels of proteins, carbohydrates and minerals. The pulp is also the principal souring agent for squashes, chutney, beverages, etc. The fruit is used in the Indian medicine as a refrigerant, carminative, antiscorbutic and laxative and is 
also prescribed for bilious disorders Roy, 1988. The active constituents present are furunone, phenyl acetaldehyde and tartaric acid. The products of the seeds are used mostly for manufacture of sizing powders (Rao, 1959). Tamarind kernel powder is extensively used for starching of cotton yarns, jute fabrics and woollen materials. The leaf sap possesses diuretic, antibacterial properties and nematode toxicity. Bark extracts reduce mosaic virus infection Tiwari, 1976. Seed husk can be used to kill predatory fish in nursery ponds (Roy, 1987).

\section{Passion fruit (Passiflora edulis)}

It is native to tropical America. It produces fruits with unique flavour and aroma for fresh eating and processing as well. Passion fruits are fair to good source of provitamin A, ascorbic acid, riboflavin and niacin and have a high mineral content. The pulp obtained after scooping from the fruits when cut in halves are added to fruit salads, ice-cream or fruit juice. Other processed products include juices, jelly, jam, squash, etc. (Menzel 1985).

\section{Importance}

Landraces and crop wild relatives have hitherto been increasingly valued and exploited for genes that provide increased biotic resistance, tolerance to abiotic stress, yield and quality (Jackson et al., 2007 and Frison et al., 2011). However, use of agricultural biodiversity should not be restricted to exploiting valuable genes for use in breeding programs if our aim is to create more robust and resilient production systems.

As a result of the Green Revolution, many of those local, traditional crop species and varieties have been replaced by high-yielding staple crop cultivars developed by modern breeding programs. Traditional crops typically do not meet modern standards for uniformity and other characteristics as they have been neglected by breeders from the private and public sectors (Stamp et al., 2012). Thus they tend to be less competitive in the marketplace compared with commercial cultivars.

Currently underutilized food sources ranging from minor grains and pulses, root and tuber crops and fruits and vegetables to non-timber forest products have the potential to make a substantial contribution to food and nutrition security, to protect against internal and external market disruptions and climate uncertainties, and lead to better ecosystem functions and services, thus enhancing sustainability (Keatinge et al., 2010).

Jain and Gupta (2013) suggested that many of these traditional crops grown for food, fiber, fodder, oil and as sources of traditional medicine play a major role in the subsistence of local communities and frequently are of special social, cultural and medicinal value. With good adaptation to often marginal lands, they constitute an important part of the local diet of communities providing valuable nutritional components, which are often lacking in staple crops.

Beside their importance for nutritional value and a source of income, diversity of these fruits also has a cultural and social value and contributes to the stability of ecosystems (Arora, 1998). Minor fruits are not so extensively cultivated, and their consumption and trade remain to be more limited. However, many are of considerable economic importance in their respective regional markets (Anang and Chan, 1999).

Considering the importance of the crops as food, medicine and for industries, these underutilized crops can be exploited at the commercial level. The high nutritional qualities indicate that the cultivation and consumption of these crops may be helpful in 
overcoming the nutritional deficiencies predominant in many rural areas of the country and boost the socio-economic condition of the society. With ever increasing population and consequent shortage of food grains, collection and utilization of various types of unutilized crops are considered very essential. The Global Action Plan for the Conservation and Sustainable Utilization of Plant Genetic Resources for Food and Agriculture, adopted at Leipzig, Germany in June, 1996, also gave clear priority to the conservation and use of minor and underutilized crop species (Priority Activity Area 20: Promoting Development and Commercialization of Underutilized Crops and Species, FAO, 1996).

\section{Strategies of conservation of underutilized fruit}

In India and its neighbouring countries, various native fruits, such as aonla, bael fruit (Aegle marmelos), jackfruit, jamun (Syzygium cuminii), karonda (Carissa congesta), Kokum (Garcinia indica) and phalsa (Grewia subinaequalis) are underutilized. Some of these might be important in the near or far future, because of their therapeutic/medicinal and nutritive value as well as their excellent flavor and very attractive appearance. Consumers today are becoming increasingly conscious of the health and nutritional aspects of their food. Underutilized fruits could play an important role in satisfying demand for nutritious, pleasantly flavoured and attractive natural food of high therapeutic value.

Encouraging local people to produce these fruits can help to improve their social and economic welfare. In this way, they can also significantly contribute to the preservation of the environment by stopping uncontrolled harvesting from the wild and assisting in the retention of the various species in their native habitats where they perform best.
Conservation is very important, because many species are becoming extinct and many others are threatened and endangered. The diversity of some fruits is well collected, while for other fruits relatively little has been done yet (Arora, 1994). Gaps in collections are found both between species and between regions. This is especially true for both underutilized species and wild crop relatives, where big gaps are noted.

Kostermans and Bompard (1993) indicate that Mangifera blommesteinii, M. leschenaultii, $M$. superba and M. paludosa are in real danger of extinction. High genetic erosion has been noted for jackfruit, Citrus sp. and Litchi chinensis in a survey carried out by the International Centre for Underutilized Crops (ICUC) and IPGRI (Haq, 1994).

Recently, Dahanayake (2015) to facilitate the conservation of these underutilized fruit crops. The main components are; Identification and collecting live samples of neglected and underutilized crop species establishment of plant arboretum for neglected and underutilized vegetables, fruits and other crop species and promote studies, research and multiplication for the benefit of future generation, conducting awareness creation and educational workshops on the medicinal and nutritional values of identified underutilized species, conducting field research and studies to identify the most suitable techniques for the growing of these plant species and introduction of identified underutilized vegetables and other crop species to the rural home gardens and facilitate the community contribution for conservation of such crop species.

\section{Ensure the availability of genetic diversity}

According to IPGRI (Padulosi, 1999) the conservation (both ex situ and in situ) of the genetic diversity of underutilized species is 
extremely poor: more than $80 \%$ of these "minor species" conserved in gene banks around the world (ca 5,000 species as a whole) are represented by just 1 to 10 accessions. This is not a sufficient base upon which characterise, develop or restore the genetic resource base of these species which may turn out to be very important for food security, income generation and environmental health. This fact indicates furthermore that the vast bulk of the genetic resources of underutilized species are in the hands of users and local communities. A successful and sustainable use of underutilized species relies on both the provision of diversity for current uses and its maintenance for future deployment. In view of the local specificity of underutilized species such two-fold objective requires however a conservation and development approach rather distinctive from that applied to other crops. Collections held in isolation from the main users are vulnerable to being lost or not maintained, as the crop may be unimportant to the country holding the genetic resources. At the same time, should the genetic resources increase in value as a result of prospecting, research, and new market opportunities, it may be more difficult to ensure that the resulting benefits are distributed to the farmers who maintained and developed the genetic diversity in the form of land races. In order to encourage the continuation of these activities germplasm should be able to flow from farmer to PGR programs and back.

For these reasons, the link between ex situ collections and in situ users of genetic diversity is fundamental for underutilized species. Research should be therefore directed towards the establishment and/ or strengthening of existing community-based efforts and integrate them with ex situ national capacities.

Concerted research efforts have been made in the recent past on domesticated and cultivated underutilized species, particularly for crop diversification for food and commerce (Bhag Mal, 1988, 1994; Paroda, 1988; Paroda and Bhag Mal, 1989, 1992; Wickens et al., 1989; Bhag Mal and Joshi, 1991; Zhou, 1992).

Several international agencies, such as the Overseas Development Agency (ODA), International Plant Genetic Resources Institute (IPGRI), United States Agency for International Development (USAID), and International Centre for Underutilized Crops (ICUC), also encouraged research on these underused species in order to broaden the range of plant species under cultivation. This has helped to raise concern and awareness for safe conservation and sustainable use of genetic resources of underutilized plant species.

\section{Strategies of improvement of Underutilized fruit}

Neglected or underutilized crops have the potential to play a number of roles in the improvement of food security in India that include being:

Part of a focused effort to help the poor for subsistence and income,

A way to reduce the risk of over-dependency on very limited numbers of major staple food crops,

A way to increase sustainability of agriculture through a reduction in inputs,

Increase the food quality;

A way to preserve and celebrate cultural and dietary diversity,

A way to use marginal and wastelands for agricultural purposes to meet the ever increasing food demand (Mayes et al., 2011). 


\section{Some underutilized crops of India}

\begin{tabular}{|l|l|l|}
\hline CROP & SCIENTIFIC NAMIE & FAMILY \\
\hline Jamun & Syzygium cumini & Myrtaceae \\
\hline Ber & Ziziphus mauritiana & Rhamnaceae \\
\hline Anola & Emblica officinalis & Euphorbiaceae \\
\hline Jackfruit & Artocarpus heterophyllus & Moraceae \\
\hline Bael & Aegle marmelos & Rutaceae \\
\hline Karonda & Carissa carandas & Apocynaceae \\
\hline Carambola & Averrhoa carambola & Oxalidaceae \\
\hline Custard Apple & Annona squamosa & Annonaceae \\
\hline Fig & Ficus carica & Moraceae \\
\hline Loguat & Eriobotrya japonica & Rosaceae \\
\hline Phalsa & Grewia subinaequalis & Tiliaceae \\
\hline Rambutan & Nephelium lappaceum & Sapindaceae \\
\hline Tamarind & Tamarindus indica & Leguminosae \\
\hline
\end{tabular}

Underutilized fruits and their products for market research

\begin{tabular}{|l|l|l|}
\hline S. No. & Underutilized fruit & Fruit product \\
\hline $\mathbf{1}$ & Aonla & $\begin{array}{l}\text { Pickle, Candy, Squash, Murabba, Dry aonla (supari) and } \\
\text { Mouth freshener or Pachan aonla (digestive aonla) }\end{array}$ \\
\hline $\mathbf{2}$ & Tamarind & $\begin{array}{l}\text { Tokku (chutney), Pickle, Paste or Concentrate, Panipuri } \\
\text { masala, Dry tamarind (powder), Candy }\end{array}$ \\
\hline $\mathbf{3}$ & Karronda & Pickle \\
\hline $\mathbf{4}$ & Jackfruit & Chips, Papad \\
\hline $\mathbf{5}$ & Citron & Pickle \\
\hline $\mathbf{6}$ & Ber & Ber powder, Salted ber \\
\hline
\end{tabular}

Gajanana et al., 2010

Current research status of underutilized fruit crops

The past three decades have seen a wide and varied range of research interests on underutilized crops. Whereas most of these interests were focused on particular projects of individual researchers, there have been a number of significant programmes to promote underutilized species for agricultural systems, as alternative crops or as sources of new products; and these programmes have been undertaken in both developing and developed countries. Additionally, there has been a broader recognition that underutilized crops should always be promoted, to improve food security. A report on current research and research proposals for enhanced cooperation on UUC's was documented by Williams and Haq (2002). Various international research organizations have been established to focus on UUC's which have been enlisted:

\section{International Centre for Underutilized Crops (ICUC)}

This is a research, development and training organization. It provides expertise and acts as a knowledge hub and supported research on national priorities for germplasm collections, agronomy and post-harvest methodology of underutilized species and associated scientific 
conferences and training events. In recent years, the focus has expanded to include processing and marketing assessments and entrepreneurship development only. ICUC have several professional networks in twenty one countries in particular as UTFANET (Underutilized Tropical Fruits in Asia Network), UTVAPNET (Underutilized Tropical Vegetables for Asia and the Pacific Network), SEANUC (Southern and East Africa Network for Underutilized Crops and ACUC (Asian Centre for Underutilized Crops) etc.

\section{Global facilitation unit (GFU)}

The GFU is a multi-institutional initiative that acts globally to promote a wider use of underutilized plant species through supporting and facilitating the work of other stakeholders. The mission rather to create an enabling environment for stakeholders who are engaged in developing underutilized species.

\section{Convention on biological diversity (CBD)}

Became a rallying point and promoted the concept of maintaining local agrobiodiversity. All these various international units which are working on underutilized species have led to a better liaison between relatively isolated groups of workers but there are still major gaps. The Consultative Group on International Agricultural Research (CGIAR) organized a workshop in 1999 at Chennai (India) followed the major FAO Global Plan of Action. One of the outcomes was a recommendation to survey all ongoing activities on underutilized species worldwide.

\section{Global facilitation unit (GFU)}

The GFU is a multi-institutional initiative that acts globally to promote a wider use of underutilized plant species through supporting and facilitating the work of other stakeholders. The mission rather to create an enabling environment for stakeholders who are engaged in developing underutilized species [Facilitation Unit (GFU) for Underutilized Species]. In addition, crops for the Future Research Centre (CFFRC), a research arm of CFF being built adjacent to UNMC is the first-of-itskind, with a global mandate for research and development of underutilized plants for food and non-food uses.

\section{Utilization of underutilized fruit}

\section{Various processed products from underutilized fruits}

The main processed products consumed by people were jam, RTS - fruit drinks, chutneys, candies, pickles, squashes, concentrate etc. (Roy, 2000; Khurdiya, 2001 a and b; Singh et al., 2008). Various processed products like canned jackfruit bulbs in syrup, squash, raw jack pickle, roasted jack seeds, jack seed flour, and candied jackfruit, have been prepared from Jack fruit (Berry and Kalra, 1998; Chadha and Pareek, 1988; Chandra and Prakash, 2009). Various processed products such as nectar, squash, slab, toffee powder, etc. can be made with Bael pulp. Ber can be processed to prepared murrabba, candy, dehydrated ber, pulp, jam, and ready-to serve beverage (Khurdiya, 1980; Pareek, 2001). Jamun fruits can be processed into excellent quality fermented and nonfermented beverages. Besides that, good quality jelly, jam, leather can be prepared. A good quality jelly can also be prepared from its fruits. The seeds can be processed into powder, which is very useful to cure diabetes (Khurdiya, 2001a and b). The main processed product made from Karonda is pickle. Ripe ber fruit is consumed as popular dessert and processed for various value added products such as murabba, candy, sharbat, squash and 
powdered fruits after drying are also consumed.

\section{Promotion of underutilized fruits}

A great deal is known about the virtues of the underutilized fruits of India. For their improvement and development by ideal propagation methods and agro-techniques should also be adopted. Being local crops and harvested from the wild or found in the home gardens, they are easily available and thereby provide food security to the people. The crops are not or little processed. Promotion for setting up of processing industries (jams, jellies, fermented products, etc) and industries for manufacturing of resins, gums, etc., lifestyle (e.g., cosmetics), etc. should also be encouraged.

Underutilized fruit crops can be used for sustainable land use since they do not require external inputs, such as irrigation or fertilization. Undomesticated landraces have adapted to a variety of ecosystems and can sometimes survive conditions which highbred cultivars cannot. The low external input requirements have also given rise to suggestions that underutilized crops production can go hand in hand with organic certification, thus opening niche market options to the producers (Hellin (2009). In addition, underutilized crops are components of mixed cropping systems, whether on terraces, agro forestry systems or home gardens. Besides, underutilized crops are integrated into the farming system and are better suited to harsh conditions than domesticated commercial crops. Since an uncertainty of climate is prevalent, a certain level of resilience can be built through increased agro-biodiversity. If one crop, or one variety, fails due to unforeseen events, others might be available to provide food or income instead.

\section{Strategies for the development of underutilized}

\section{Horticultural crops}

Afforestration and rejuvenation of degraded forests may be carried out with emphasis on supplementing and enriching biodiversity of edible food/horticultural crops. Joint forest management programmes should facilitate spread of ITK available with local communities on sustainable collection and use of various edible species.

Domestication of potential wild species through homestead cultivation should be encouraged for avoiding over-exploitation from natural sources. Supports are required in terms of multiplication of planting materials and their distribution besides providing market access through Imarketing network for perishables.

Under-utilized horticultural crops are nutritionally rich and adapted to low input agriculture. More R \& D efforts in these will add substantially to food security and nutrition vis-à-vis human welfare.

Limited number of species needs to be targeted for detailed research and development in under-utilized horticultural crops by national programmes focusing on their conservation and use. Research needs to be geared up both on species/crops important for subsistence farming and those exhibiting potential to become commodity crops.

Under-utilized horticultural crops are mainly grown/managed under traditional farming systems by diverse ethnic communities. Increased focus to document indigenous knowledge is required such as through ethobotanical studies. Such emphasis will help tap value additions as much of native diversity is put to multipurpose uses. 
Strategies need to be worked out particularly at national and regional levels to develop and make available promising selections/varieties, overcoming constraints of production of good seed material, planting material, invitro/tissue cultured material etc. This would boost production, meeting local needs, promoting domestic markets and thereby, enhance income generation of small farming communities.

Systematic local specific crop planning in accordance with agro-climatic suitability of the region is needed to be done.

These underutilized fruit resources can be used to combat malnutrition, hunger and to reduce burden on overexploited fruits. Adaptation of new fruit sources will bring the unexploited underutilized and neglected plants into mainstream of consumption. There is an urgent need for the conservation and protection of these plants of future. Wild edible Fruits (WEF) are not only sources of food and nutrients to the local communities, but could also be means of income generation, if managed sustainably. Several other WEF can benefit local people not only as food, but also for their medicinal properties. These multivalued resources are threatened by several anthropogenic and natural causes such as land-use change, habitat destruction, over-harvesting, overgrazing, and invasive species. Therefore, sustainable management of these resources for the well being of the local communities as well as to conserve biodiversity is of the utmost importance and could also contribute to preserve cultural and genetic diversity. Inclusion of WEF in community forest management plans would be the most realistic conservation and livelihood approach for the study areas as most forests are managed by community forest user groups. A scientific investigation of wild edible fruits is urgently needed to assess the potentiality which would be cultivated and utilized as a source of food material for an ever increasing population.

\section{References}

Achenbach, H., Naibel, R., Addae Mer Sah 1989. Phytochemistry 24: 2325-2328.

Agent, 1994. A survey of the market for fruits and vegetables in the hotel and restaurant industry, Agent's business production, processing and marketing information centre, Issue No 19, Colombo, 25.

Anang and Chang, 1999. Tropical and Subtropical Fruit. Available from http://www.enotes. com.

Arora, R.K. 1994. Promoting conservation and use of tropical fruit species in Asia. Pp. 1930 in

Arora, R.K., 1998. Promoting conservation and use of tropical fruit species in Asia. Available from http://www2.bioversity international.org.

Asia, New Delhi, India.

Berry, S.K. and Kalra, C.L. (1987). Cultivation and processing of jackfruit. Indian Ed Pack., 42(5): 62-67.

Chadha, K.L. and Pareek, O.P. (1988). Genetic resources of fruits crops: achievements and gaps. Indian J. Pl. Genet. Resour., 1: 43-48.

Chandra, D.S. and Prakash, J. (2009). Minor fruits: a livelihood opportunity for the tribal peoples of Tripura. IInd International Symposium on pomegranate and minor including Mediterranean fruits, ISPMMF 2009.

Cheema, G.S., Cheema, B.K. 1971. Farm J Calcutta 12: 24

Dansi, A., Vodouh, R., Azokpota, P., Yedomonhan, H., Assogba, P. and Adjatin, A. 2012. Diversity of the Neglected and Underutilized Crop Species of Importance in Benin. The Scientific World Journal, 119.

Das, S.C., Prakash, J., Deb, A.K., Biswas, T. 2013. Medicinal Value of Underutilized Fruits in Hilly Tripura. Acta Hort, 972: 135-141.

FAO. 1996. Global plan of action for the conservation and sustainable utilization of plant genetic resources for food and 
agriculture. Food and Agriculture Organization of the United Nations, Rome, Italy.

Font, Quer, P. 1973. Plantas Medicinales. El Dioscorides Renovadol Editirial Labor, Barcelona, Spain.

Frison, E.A., Cherfas, J. and Hodgkin, T. 2011. Agricultural biodiversity is essential for a sustainable improvement in food and nutrition security. Sustainability, 3: 238253.

Gajanana, T.M., Gowda, I.N.D. and B.M.C. 2010. Reddy Exploring Market Potential and Developing Linkages - A Case of Underutilized Fruit Products in India. Agricultural Economics Research Review, 23:437-443

Haq, H. 1994. Analysis of questionnaire to select priority species for research and development in Asia. Pp. 31-43 in Proceedings of Expert Consultation on Tropical Fruit Species of Asia, MARDI, Kuala Lumpur, Malaysia, 17-19 May 1994 (R.K. Arora and V. Ramanatha Rao, eds.). IPGRI Office for South Asia, New Delhi, India.

Hasan, M.A., Singh, S.R., Majhi, D., Devi, H.L., Somi, Singh, Y. 2010. Significance of minor fruits in health care. Proc Botanicals in Integrated Health Care 162-166.

Hellin, J., Higman, S. 2009. Underutilized plant products and market access: challenges and opportunities. Acta Hort, 806: 393-406.

Iyer, U., Joshi, A., Dhruv, S. 2009. Impact of amla (Emblica officinalis) supplementation on the glycemic and lipidemic status of type 2 diabetic subjects. J Herbal Medicine and Toxicol 3(2): 15-21.

Jackson, L.E., Pascual, U., Hodgkin, T. 2007. Utilizing and conserving agrobiodiversity in agricultural landscapes. Agric. Ecosyst. Environ., 121: 196-210.

Jaenicke, H. and Hoschele-Zeledon I. 2006. Strategic Framework for Underutilized Plant Species Research and Development, with Special Reference to Asia and the Pacific, and to Sub-Saharan Africa. Rome, Italy: International Centre for Underutilized Crops, Colombo, Sri Lanka and Global Facilitation Unit for Underutilized Species.
Jain, S.M. and Gupta, S.D. 2013. Eds.; Biotechnology of Neglected and Underutilized Crops; Springer: Berlin, Germany.

Keatinge, J.D.H., Waliyar, F., Jamnadass, R.H., Moustafa, A., Andrade, M., Drechsel, P., Hughes, J. 2010. Re-learning old lessons for the future of food-by bread alone no longer: Diversifying diets with fruit and vegetables. Crop Sci., 50: 51-62.

Khurdiya, D.S. (1980). A new beverage from dried ber (Zizyphus mauritiana Lam). J. Food Sci. Technol., 17: 158-159.

Khurdiya, D.S. (2001a). Post-harvest management of underutilized for fresh marketing. Winter school on exploitation of underutilized fruits, 266-274.

Khurdiya, D.S. (2001b). Post-harvest management of underutilized fruits for processed products. Winter school on exploitation of underutilized fruits, 291-298.

Kostermans, A.J.G.H. and J.M. Bompard. 1993. The Mangoes, their Botany, Nomenclature, Horticulture and Utilization. IBPGR and the Linnean Society of London.

Krivencov, V.I., Karahanova, S.V., Savina, G.G. 1970. Bjull. Gos. Nikitsk. Bot Sada 2: 5759.

Kunkel, G. 1984. Plants for human consumption. Koeltz Scientific Books, Koenigstein, Germany.

Magbagbeola, J.A., Adetoso, J.A. and Owolabi, O.A. 2010. Neglected and underutilized species (NUS): panacea for community focused development to poverty alleviation/poverty reduction in Nigeria. Journal of Economics and International Finance, 2: 208-211.

Malaysia, 17-19 May 1994 (R.K. Arora and V. Ramanatha Rao, eds.) IPGRI Office for South

Mayes, S., Massawe, P.G., Alderson, J.A., Roberts, S.N., Azam- Ali and Hermann, M. 2011. The potential for underutilized crops to improve security of food production. $J$. Exp. Bot., 1-5.

Menzel, C.M., Winks, C.W., Simpson, D.R. 1985. Passion fruit. In: Bose TK, (Eds.), Fruits: Tropical and Subtropical, Naya Udyog, India. 2: 361-410. 
Mitra, S.K. 1999. Tropical Horticulture In: Bose TK, et al., (Eds), Naya Prakash, India, 1: 784.

Morsli, A., Bellal, M., Ammouche, A. 1985. Annales de L' Inst. Nat Agronomique 9: 63-64.

Nalawadi, U.G., Jayasheela, N. 1975. Progressive Hort, 7: 37-38.

Nilanthi Dahanayake 2015, some neglected and underutilized fruit-crops in Sri Lanka International Journal of Scientific and Research Publications, 5(2): 2250-3153

Pareek, O.P. (2001). Ber. International Centre for Crops. Southampton (U.K.).

Polumin, O., Huxley, A. 1965. Flowers of the Mediterranean. Chatto and Windus, London.

Proceedings of Expert Consultation on Tropical Fruit Species of Asia, MARDI, Kuala Lumpur,

Rao, P.S. 1959. Industrial gums, Academic press, New York, USA.

Roy, P., Mazumder, B.C. 1988. Sci Cult 55: 110111.

Roy, R.N., Maiti, S.S., Mondal, C.R. 1987. Environ Ecol., 5: 467-471.

Roy, S.K. (2000). Promotion of underutilized tropical fruit processing and its impact on world trade. Retrieved from: http:// www.actahort.org/books/518/518_31.htm. Acta Hort., (ISHS) 518: 233-236.

Salvi, J. and Katewa, S.S. 2016. Underutilized wild edible plants as a potential source of alternative nutrition. International Journal of Botany Studies, 1(4): 32-36.

Singh, D., Wangshu, L. and Prahalad, V.C. (2008). Processing and marketing feasibility of underutilized fruit species of Rajasthan. IAMO Forum, pp. 1-12.

Singh, S.J., Batra, V.K., Singh, S.K. and Singh, T.J. 2012. Diversity of underutilized vegetable crops species in North- East India with special reference to Manipur: $A$ review. NeBIO. 3 (2): 87-95.

Stamp, P., Messmer, R., Walter, A. 2012. Competitive underutilized crops will depend on the state funding of breeding programmes: An opinion on the example of Europe. Plant Breeding, 131: 461-464.

Tiwari, J.P. 1976. Curr Sci 45: 696-697.

Williams, J.T. and Haq, N. 2002. Global research on underutilized crops - an assessment of current activities and proposals for enhanced cooperation. Southampton, UK: International Centre for Underutilized Crops.

\section{How to cite this article:}

Simrandeep Kour, Parshant Bakshi, Arti Sharma, V.K. Wali, Amit Jasrotia and Shilpy Kumari. 2018. Strategies on Conservation, Improvement and Utilization of Underutilized Fruit Crops. Int.J.Curr.Microbiol.App.Sci. 7(03): 638-650. doi: https://doi.org/10.20546/ijcmas.2018.703.075 